\title{
VALUASI EKONOMI SUMBERDAYA TERUMBU KARANG KEPULAUAN BANDA KABUPATEN MALUKU TENGAH PROVINSI MALUKU
}

\author{
Abdul Rahim Lestaluhu, Jahra Wasahua \\ Staf Pengajar FKIP, UNIDAR-Ambon, e-mail : -
}

\begin{abstract}
ABSTRAK
Kepulauan Banda memiliki keanekaragaman terumbu karang dan ikan karang yang tinggi untuk ukuran standar dunia, yang keberadaanya terancam oleh aktifitas manusia. Penelitian ini untuk mengetahui produksi perikanan karang dan menilai manfaat perikanan karang (surplus produsen) untuk menaksir nilai ekonomi terumbu karang Kepulauan Banda. Penentuan responden dari populasi target digunakan teknik convenience (hapzard atau accidental). Responden sebanyak 22 rumah tangga perikanan. Hasil penelitian menunjukkan bahwa produksi perikanan karang sebesar $54.539 \mathrm{~kg} / \mathrm{tahun}$, dan NPV terumbu karang Kepulauan Banda yang luasnya 15 ha dengan suku bunga 13,66 dalam jangka panjang adalah sebesar $R p$ 5.274.099.817. Nilai ekonomi lestari terumbu karang Kepulauan Banda ini yang juga merupakan biaya korbanan yang ditanggung bila sumberdaya terumbu karang Kepulauan Banda mengalami kerugian.
\end{abstract}

Kata Kunci: Kepulauan Banda, surplus produsen, perikanan karang, NPV

\section{PENDAHULUAN}

\subsection{Latar Belakang}

Kepulauan Banda atau Kecamatan Kepulauan Banda terdiri dari 11 pulau, 6 pulau berpenghuni dan 5 pulau tidak berpenghuni, dengan luas daratannya $172 \mathrm{~km}^{2}$. Merupakan wilayah administratif pemerintahan Kabupaten Maluku Tengah Provinsi Maluku, pada posisi geografis 04031' S dan 129054' BT di Laut Banda, bagian selatan wilayah Indonesia. Berdasarkan Surat Keputusan Menteri Kelautan dan Perikanan No. KEP.69/MEN/2009 tentang Penetapan Cagar Alam Laut Banda menjadi Kawasan Konservasi Perairan Nasional Taman Wisata Perairan Laut Banda.

Kepulauan Banda memiliki sumberdaya terumbu karang seluas 15 ha. Studi yang dilakukan oleh Turak et al. (2002), dilaporkan bahwa di kawasan ini pada umumnya terumbu karang tumbuh dalam formasi terumbu karang tepi (fringing reefs) dan lebih dari 300 spesies karang keras yang tercatat, yang memiliki standar dunia yang tinggi yang diberikan oleh area terumbu karang yang kecil. Disamping itu keanekaragaman hayati ikan karang yang ada di kawasan ini juga tinggi. Penelitian yang dilakukan oleh Halford (2002) dilaporkan terdapat $\mathbf{5 0 0}$ spesies ikan karang dari $\mathbf{5 0}$ famili telah diamati, dengan mempertimbangkan kecilnya luas permukaan Kepulauan Banda, keeanekaragaman ini sangat tinggi, yang merefleksikan tingginya nilai pelestarian dari kepulauan yang kecil ini.

Manfaat yang diperoleh dari kawasan konservasi ini berupa tempat penangkapan ikan nelayan tradisional baik lokal maupun nelayan dari daerah lain, tempat wisata bahari, tercatat wisatawan bahari yang datang mengunjungi Kepulauan Banda pada tahun 1991 sekitar 600 orang, dan pada tahun 1994 naik menjadi 1500 (Terangi, 2000). Selain itu kawasan ini juga dimanfaatkan sebagai tempat penelitian terumbu karang, baik oleh peniliti lokal maupun peniliti asing diantaranya (Terangi, 2000).

Tantangan yang dihadapi dalam pengelolaan terumbu karang Kepulauan Banda ini terutama oleh ancaman manusia. Ancaman berupa penangkapan ikan dengan menggunakan bahan peledak (UNESCO, 1995 


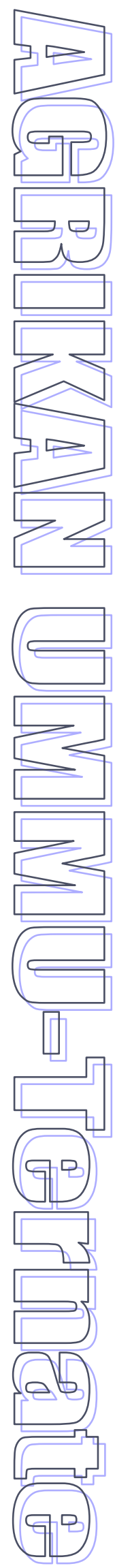

dalam Terangi, 2000), penambangan karang, penggunaan alat tangkap bubu, penampungan ikan karang hidup yang mendorong penggunaan potasium sianida dan kalium sianida, perdagangan bahan bakar minyak (BBM) di atas perairan laut (Djuharsa dan Suhendi, 2002).

Biodiversitas terumbu karang dan ikan karang yang tinggi ini merupakan asset sumberdaya yang berharga, dan ancaman terhadapnya mendorong untuk dilakukan penelitian valuasi ekonomi sumberdaya terumbu karang Kepulauan Banda, dengan cara melakukan identifikasi manfaat dan dampak biofisik pemanfaatan sumberdaya terumbu karang, mengkuantifikasi dampak dan manfaat tersebut, dan memberikan unit harga. Nilai ekonomi ini menjadi lebih bersifat obyektif dalam mengukur potensi dari sumberdaya terumbu karang Kepulauan Banda, sehingga terhindarkan penilaian yang under value atau sebaliknya over value.

Valuasi ekonomi terhadap potensi sumberdaya terumbu karang tersebut merupakan salah satu instrumen yang efektif untuk pengambilan keputusan, dalam kaitannya dengan pengelolaan sumberdaya terumbu karang yang optimal dan lestari dari perspektif ekonomi. Dengan dilakukannya valuasi ekonomi diharapkan dapat menjadi masukkan berharga untuk menghasilkan keputusan yang baik melalui masukkan analisis ekonomi, analisis keuangan dan analisis nilai manfaat serta biaya dari sumberdaya terumbu karang.

\subsection{Perumusan Masalah}

Sumberdaya atau ekosistem terumbu karang Kepulauan Banda memiliki biodiversitas yang tinggi, dan keberadaanya sangat mempengaruhi dinamika kawasan perairan di sekitarnya. Berbagai biota laut sangat tergantung pada terumbu karang ini, seperti ikan karang yang dari hasil penelitian tercatat 500 jenis. Ketergantungan ini dikarenakan terumbu karang mempunyai fungsi ekologis sebagai habitat (Costanza et al. 1997) dan sebagai tempat pemijahan, pengasuhan, dan mencari makan untuk banyak mahluk hidup (Moberg dan Folke, 1999). Peran fungsional terumbu karang ini akan mendukung produktivitas perikanan yang akan menyediakan sumber makanan atau protein bagi masyarakat di sekitarnya.

Sumberdaya ini juga rentan terhadap gangguan yang dapat menimbulkan kerusakan, terutama oleh faktor anthropogenik. Dalam kasus Indonesia, hasil studi Cesar (1996) dilaporkan ada lima ancaman utama terhadap terumbu karang di Indonesia oleh karena faktor anthropogenik yang mendorong terjadinya kemorosotan yaitu, penangkapan ikan dengan racun, penangkapan ikan dengan bahan peledak, penambangan karang, sedimentasi dan polusi, dan tangkap lebih. Laporan ini didukung oleh studi oleh Burke et al. (2002) menyatakan bahwa aktivitas manusia mengancam lebih dari $85 \%$ terumbu karang Indonesia. Ancaman utama ini berupa penangkapan ikan secara berlebihan dan penangkapan ikan dengan metode yang merusak, pembangunan pesisir dan sedimentasi dari daratan. Demikian pula untuk terumbu karang di wilayah Maluku, dari hasil studi oleh Hopley dan Suharsono (2000) dilaporkan sekitar $65 \%$ menunjukkan kerusakan akibat bahan peledak.

Sementara itu ancaman terhadap terumbu karang Kepulauan Banda, merujuk pada laporan UNESCO (1995) dalam Terangi (2000) dan Djuharsa dan Suhendi (2002), ancaman yang teridentifikasai adalah penangkapan ikan menggunakan bahan peledak, penggunaan alat tangkap bubu, penampungan ikan karang hidup yang dikhuatirkan mendorong penggunaan potasium sianida dan kalium sianida, perdagangan bahan bakar minyak (BBM) di atas perairan laut. Ancaman-ancaman tersebut akan berdampak pada rusak dan matinya terumbu karang yang kemudian berkuranganya luas tutupan karang hidup. Seperti diketahui bahwa tutupan karang hidup ini mempengaruhi keaneka-ragaman dan kelimpahan jenis dari komunitas ikan karang (Bel dan Galzin, 1984; Chabanet et al., 1997; Anderson, 2002; Jones et al., 2004).

Medrizam dkk., (2004) menjelaskan bahwa, ancaman-ancaman ini dapat menyebabkan kemerosotan, penyusutan dan pelenyapan ekosistem. Kemerosotan ekosistem ini ditandai dengan kemerosotan kinerja dan 


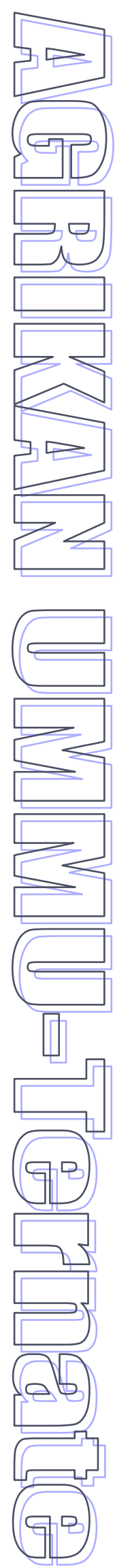

mutu fungsi ekosistem akibat berbagai faktor penyebab. Dapat digambarkan dengan menurunnya kemampuan produksi setempat, misalnya semakin kecilnya nilai tangkapan per satuan usaha (catch per unit effort, CPUE) di bidang perikanan karang. Penyusutan ekosistem ditandai dengan berkurangnya luasan tutupan habitat penting, juga mencakup fragmentasi habitat. Pelenyapan ekosistem digambarkan dengan lenyapnya keberadaan ekosistem di suatu wilayah akibat berbagai faktor penyebab.

Berdasarkan potensi dan permasalahan yang dihadapi oleh terumbu karang TWP Laut Banda tersebut menumbuhkan pertanyaan yang diajukan dalam penelitian ini. Dalam kondisi sumberdaya atau ekosistem terumbu karang TWP Laut Banda yang terancam tersebut: (i) berapa produksi perikanan karang di TWP Laut Banda; dan (ii) berapa nilai ekonomi manfaat tidak langsung (indirect use value) terumbu karang TWP Laut Banda untuk jasa tempat pemijahan, pengasuhan dan mencari makan bagi ikan karang ekonomis.

\subsection{Tujuan Penelitian dan Manfaat}

Penelitian ini dilakukan dengan beberapa tujuan, yaitu sebagai berikut:

1. Mengetahui produksi perikanan karang di perairan terumbu karang Kepulauan Banda.

2. Menilai manfaat perikanan karang (surplus produsen) untuk mengestimasi nilai terumbu karang Kepulauan Banda.

Manfaat yang diharapkan dari penelitian ini adalah sebagai berikut:

3. Bagi peneliti sebagai sarana untuk melakukan verifikasi terhadap keberadaan sumberdaya terumbu karang dalam kaitan dengan fungsinya sebagai penunjang kehidupan ikan karang yang manfaatnya dirasakan oleh masyarakat sekitar.

4. Sebagai masukkan untuk menentukan alternatif pemanfaatan sumberdaya terumbu karang Kepulauan Banda secara bijaksana dan proporsional.

5. Merupakan data dasar untuk menunjang penelitian tentang valuasi ekonomi sumberdaya terumbu karang berdasarkan fungsi dan jasa lainnya.

\section{METODE PENELITIAN}

2.1. Waktu dan Lokasi Penelitian

Penelitian ini dilaksanakan pada bulan November 2011, dengan lokasi Pasar Banda Desa Nusantara, Merdeka, Kampung Baru dan Tanah Rata.

\subsection{Teknik Pengambilan Contoh}

Contoh nelayan ditentukan dengan menggunakan metode purposive sampling, sampel ditentukan secara tidak acak, yaitu berdasarkan pertimbangan bahwa nelayan responden adalah nelayan yang menangkap ikan karang di kawasan perairan terumbu karang Kepulauan Banda. Karena tidak tersedianya data nelayan perikanan karang, cara untuk pengambilan sampel dilakukan dengan teknik convenience (hapzard atau accidental) yaitu prosedur memilih responden yang paling mudah tersedia, sembarang atau kebetulan ditemui (Juanda, 2007). Dalam studi ini sampel tersebar di Desa-desa sebagai berikut: Kampung Baru, Nusantara, Pasir Panjang, Pulau Ay, Pulau Pisang, Pondok, Merdeka, Tanah Rata, dan Kapal Tuna.

\subsection{Metode Analisa Data Ekonomi}

Analisa data yang dilakukan pada penelitian ini didasarkan pada batasan-batasan:

1) Ikan karang ekonomis hasil tangkapan sebagai produk akhir dari sumberdaya terumbu karang merupakan ikan karang ekonomis hasil tangkapan nelayan perikanan karang di kawasan perairan terumbu karang TWP Laut Banda. Untuk mengetahui apakah hasil tangkapan nelayan ikan karang merupakan ikan karang ekonomis, dalam penelitian ini digunakan buku Petunjuk Identifikasi Ikan-ikan Laut Ekonomis Penting di Indonesia karangan Peristiwady (2006).

2) Untuk melakukan analisa finansial terlebih dahulu ikan-ikan karang ekonomis hasil tangkapan nelayan dikelompokkan berdasarkan hubungannya dengan peran fungsional terumbu karang sebagai tempat pemijahan, pengasuhan dan tempat mencari makan.

3) Analisa finansial usaha dihitung berdasarkan harga rata-rata ikan hasil 
tangkapan dan rata-rata biaya yang dikeluarkan oleh unit perahu.

Penelitian ini menggunakan analisa biayamanfaat untuk mendapatkan nilai ekonomi sumberdaya terumbu karang Kepulauan Banda, dan oleh karena merupakan Kawasan Konservasi Laut (KKL) maka dalam perhitungan nilai ekonominya mengadopsi perhitungan manfaat ekonomi KKL yang dilakukan oleh Fauzi dan Anna (2005). Dimana tahapan awal dalam analisa biaya-manfaat untuk KKL ini terlebih dahulu dibuat tampilan finansial dari kegiatan perikanan karang yang ada pada saat ini. Nilai akhir yang diperoleh adalah menggambarkan nilai ekonomi dalam kondisi saat ini.

Tampilan finansial tersebut digambarkan melalui tiga indikator utama nilai ekonomi yakni Penerimaan Bersih (net revenue), Nilai Tambah (value added) dan Pendapatan Perahu (boat income) yang merupakan proksi dari surplus produsen. Masing-masing indikator ekonomi tersebut oleh Fauzi dan Anna (2005) dijelaskan sebagai berikut: (i) Penerimaan bersih didefinisikan sebagai selisih antara penerimaan dan biaya operasi; (ii) Nilai tambah merupakan selisih antara penerimaan bersih dan biaya tetap per perahu. Nilai tambah ini merupakan rente ekonomi karena sudah menggambarkan selisih antara total penerimaan dari sumberdaya ikan karang, yang merupakan output dari ekosistem terumbu karang, dengan seluruh biaya yang dikeluarkan untuk mengekstrasi sumberdaya tersebut; dan (iii) Pendapatan perahu merupakan nilai akhir yakni selisih antara Nilai tambah dan total biaya tenaga kerja.

Oleh karena manfaat sumberdaya terumbu karang juga menyangkut manfaat jangka panjang maka manfaat ekonomi terumbu karang di perairan Kepulauan Banda dihitung dengan memperhatikan aspek intertemporal tersebut. Menurut Fauzi (2004) bahwa pilihan intertemporal menyangkut membandingkan nilai atau manfaat ekonomi dari sumberdaya alam pada periode waktu yang berbeda, dimana pengambilan keputusan yang bersifat intertemporal adalah melalui proses discounting.

Lebih lanjut lagi menurut Fauzi (2004) bahwa, karena adanya faktor inflasi yang sangat berkorelasi erat dengan suku bunga, maka pengukuran nilai suku bunga harus diukur dalam nilai riil, yaitu selisih antara suku bunga nominal dengan laju inflasi. Ini dapat dipahami, bahwa dalam dimensi ekonomi makro suku bunga merupakan instrument untuk mengkopensasi inflasi, maka inflasi rendah, atau malah nol, adalah cocok untuk upaya pelestarian ekosistem atau sumberdaya alam. Dalam penelitian ini memakai suku bunga riil $13,66 \%$, selisih antara suku bunga nominal $14 \%$ dan laju inflasi pada saat penelitian 0,34\% (November 2011).

Dengan mengadopsi formula Fauzi dan Anna (2005), maka Present Value dari manfaat ekonomi terumbu karang Kepulauan Banda dalam jangka panjang dihitung sebagai berikut (Fauzi dan Anna, 2005):

$$
P V=\sum_{t=0}^{\infty}\left[\frac{1}{1+\delta}\right]^{t-1}\left[\sum_{i=1}^{n} \sum_{j=1}^{m} p_{i j} h_{i j} E_{i j}-c_{i j} E_{i j}-w_{j}\left(p_{i j} h_{i j} E_{i j}-c_{i j} E_{i j}\right)-F C_{i j}\right]
$$

dimana:

$$
\begin{aligned}
p_{i j}= & \text { harga ikan oleh perahu } \mathrm{i} \text { pada lokasi } \mathrm{j} . \\
h_{i j}= & \text { cath rate perahu } \mathrm{i} \text { pada lokasi } \mathrm{j} . \\
E_{i j}= & \text { unit input (effort) yang digunakan oleh } \\
& \text { perahu i pada lokasi } \mathrm{j} . \\
c_{i j}= & \text { biaya per unit input }(\text { effort }) . \\
w_{j}= & \text { biaya tenaga kerja pada lokasi } \mathrm{j} . \\
F C_{i j}= & \text { biaya tetap dari alat i pada lokasi } \mathrm{j} .
\end{aligned}
$$

Adapun biaya tetap merupakan penjumlahan dari pengeluaran untuk alat tangkap dan sarana alat tangkap. Untuk sarana alat tangkap penghitungannya berdasarkan depresiasi, dalam penelitian ini digunakan waktu selama 10 tahun dengan asumsi dalam kurun waktu tersebut modal untuk pembelian sarana alat tangkap sudah kembali, titik impas.

Pada tahapan pertama perhitungan nilai ekonomi ini, maka tampilan finansial terlebih dahulu diukur per unit perahu, setelah itu untuk nilai agregat ekonomi terumbu karang di Kepulauan Banda dengan luasan 15 ha dihitung dari nilai per perahu dengan total perahu yang beroperasi di KKL tersebut. Hasil perhitungan ini merupakan nilai ekonomi aktual terumbu karang, yang kemudian digunakan sebagai nilai dasar untuk melakukan estimasi dalam luasan per hektar.

Dengan mengumpulkan data harga ikan (P), jumlah upaya tangkap (E) dan perubahan luasan terumbu karang (W), maka dapat diduga nilai sumberdaya terumbu karang berdasarkan fungsinya terhadap produktifitas perikanan. Dalam hal ini metode yang digunakan 


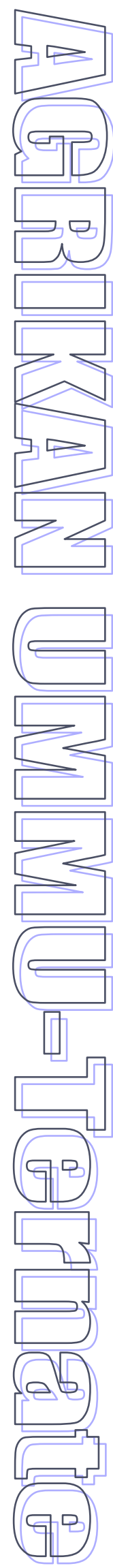

berdasarkan pada pendekatan effect on production (EoP). Teknik EoP yang digunakan adalah Present Value Generate Per Hectare, Model-Income Approach.

Teknik ini dilakukan dengan mengkapitalisasi atau mendiskon aliran bersih dari manfaat terumbu karang (produksi ekologis-biologis) yang diambil sebagai indikator nilai sekarang dari terumbu karang. Dengan membagi total nilai sekarang dari produksi terumbu karang dengan luas terumbu karang, akan diperoleh nilai sekarang per hektar dari sumberdaya terumbu karang. Pendekatan ini mengabaikan biaya produksi yang dikeluarkan baik yang berasal dari tenaga kerja atau faktor produksi lainnya.

Pendekatan ini dapat dijabarkan sebagai berikut:

$$
\text { Present value/Hectare Model }=\frac{\left(\frac{\sum \mathrm{B}_{\mathrm{t}}}{(1+\mathrm{r})^{\mathrm{t}}}\right)}{\mathrm{L}}
$$

dimana:

$B_{\mathrm{t}} \quad=$ manfaat dari sumberdaya terumbu karang Kepulauan Banda per tahun.

t $=$ jumlah tahun proyeksi.

r = tingkat discount rate.

L = luas kawasan terumbu karang Kepulauan Banda.

Sedangkan untuk menghitung residual rent, yang definisikan sebagai perubahan antara biaya faktor produksi dan nilai panen dari sumber daya terumbu karang, adalah sebagai berikut:

Present value Residual/Hectare Model $=\frac{\left(\frac{\sum \mathrm{B}_{\mathrm{t}}-\mathrm{C}_{\mathrm{t}}}{(1+\mathrm{r})^{\mathrm{t}}}\right)}{\mathrm{L}}$ dimana:

$B_{\mathrm{t}} \quad$ = manfaat dari sumberdaya terumbu karang Kepulauan Banda per tahun.

$\mathrm{C}_{\mathrm{t}}$ = biaya produksi per tahun.

t $\quad$ jumlah tahun proyeksi.

$r \quad$ = tingkat discount rate.

L = luas kawasan terumbu karang Kepulauan Banda.

Residual rent dapat dilihat sebagai kontribusi sistem alam atau faktor pendapatan (income factor) terhadap nilai ekonomi total (Barton, 1994).

\section{HASIL DAN PEMBAHASAN}

3.1. Produksi Perikanan Karang di Kawasan Perairan Terumbu Karang Kepulauan Banda

\subsubsection{Keragaman hasil tangkapan}

Ikan-ikan karang ekonomis hasil tangkapan yang dapat diidentifikasi adalah sebagai berikut: 2 ordo (Perciformes dan Beryciformes), 9 famili (Achanturidae, Holocentridae, Lutjanidae, Mullidae, Serranidae, Carangidae, Haemulidae, Priacanthidae dan Sphyraenidae), dan 23 jenis. Persentase keragaman famili yang tertinggi adalah ordo Perciformes, yang terdiri dari 8 famili $(88,89 \%)$, selebihnya ordo Beryciformes 1 famili (11,11\%). Persentase keragaman jenis yang dominan adalah famili Lutjanidae 7 jenis (30,43\%), Serranidae 6 jenis (26,09\%), Carangidae 3 jenis (13,04\%), Holocentridae 2 jenis $(8,70 \%)$, dan Sphyraenidae, Mullidae, Achanturidae, Priacanthidae dan Haemulidae masing-masing 1 jenis $(4,35 \%)$. Keragaman hasil tangkapan ikan karang ekonomis ini ditampilkan pada Tabel 1.

Mengacu penggolongan ikan karang menurut Choat dan Bellwood (1991), maka ikan karang hasil tangkapan seperti family Achanturidae tergolong reef fish. Sementara famili Lutjanidae, Serranidae, Carangidae, Holocentridae, Sphyraenidae, Mullidae, Priacanthidae dan Haemulidae kategori reefassociated species. Dengan demikian diasumsikan ikan-ikan karang ini memanfaatkan terumbu karang sebagai tempat pengasuhan dan tempat mencari makan.

Dalam kaitannya dengan habitat, ikan-ikan karang tersebut umumnya berhubungan dengan terumbu karang. Menurut Polunin dan Roberts (1993), banyak ikan menghabiskan keseluruhan hidupnya di terumbu karang, terumbu karang juga bertindak sebagai tempat pemeliharaan dan pengasuhan untuk banyak ikan lain.

Berkaitan dengan cara pemijahan dari ikan-ikan karang hasil tangkapan, keseluruhannya tergolong pola pemijahan spawns pelagic eggs. Dengan demikian tidak ditemukan ikan-ikan karang ekonomis dengan pola pemijahan spawns demersal eggs, seperti famili Balistidae dan Monacanthidae. Dari hasil observasi dan penelusuran wawancara dengan para pedagang di Pasar Banda, bahwa jenis-jenis ikan yang tergolong famili ini, seperti ikan tatu (Triggerfishes), tidaklah tergolong sebagai ikan 


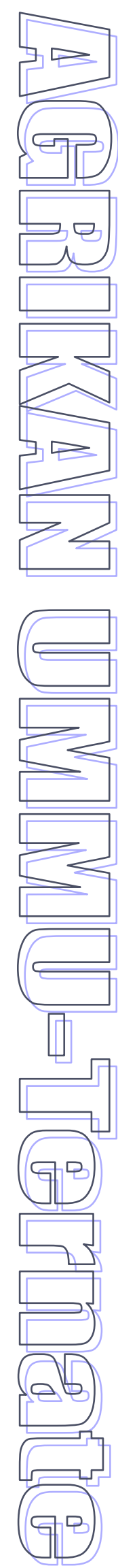

target, karena tidak bernilai ekonomis. Hasil ini berbeda dengan penelitian yang dilakukan oleh Lestaluhu (2008) di Taman Wisata Alam Laut (TWAL) Pulau Pombo. Para nelayan perikanan Nama Umum dan Lokal

Sumber: Data Primer, 2011

\subsubsection{Produksi Ikan Karang}

Terumbu karang Kepulauan Banda seluas 15 hektar $\left(0,15 \mathrm{~km}^{2}\right)$ dan dalam kondisi baik atau tutupan 50 - 70\% (Letemia dkk., 1996; Suharsono, 1995 dalam Terangi, 2000), menghasilkan ikan karang sebanyak $54.539 \mathrm{~kg} /$ tahun. Dengan perincian sebagai berikut: Serranidae $4.795 \mathrm{~kg}$ (9,05\%), Lutjanidae $20.725 \mathrm{~kg} \quad(39,43 \%)$, Carangidae $16.430 \mathrm{~kg}$ (31,26\%), Mullidae $153 \mathrm{~kg}$ (0,29\%), Achanturidae 504 kg (0,96\%), Priacanthidae $359 \mathrm{~kg}(0,68 \%)$, Sphyraenidae 4.855 kg (9,24\%), Haemulidae $1.425 \mathrm{~kg}(2,71 \%)$, dan Holocentridae $3.349 \mathrm{~kg}(6,37 \%)$.

Laporan dari studi-studi sebelumnya menunjukkan bahwa produktifitas perikanan ekosistem terumbu karang cukup tinggi. Snedaker dan Getter (1985) dalam Supriharyono (2007), memperkirakan bahwa hasil (standing crop) perikanan yang berasal karang yang berakivitas di kawasan perairan TWAL ini menjadikan ikan tatu sebagai target tangkapan.

Tabel 1. Hasil Tangkapan Ikan Karang Ekonomis di Kepulauan Banda Berdasarkan Ordo, Famili, Jenis,

\begin{tabular}{|c|c|c|c|c|}
\hline Ordo & Famili & Jenis & Nama umum & Nama lokal \\
\hline \multirow[t]{21}{*}{ Perciformes } & \multirow[t]{6}{*}{ Serranidae } & Variola albimarginata & $\begin{array}{l}\text { Yellow-edge Lunar Tail; } \\
\text { Lyretail Trout }\end{array}$ & Geropa merah \\
\hline & & Epinephelus ongus & Speckled-fin Rockcod & Geropa \\
\hline & & Epinephelus microdon & Small-toothed Cod & Geropa \\
\hline & & Gracila pollen & Blue lined Grouper & Garopa \\
\hline & & Cephalopholis boenack & Brown-banded Rockcod & Garopa \\
\hline & & Cephalopholis miniata & Coral Cod & \\
\hline & \multirow[t]{7}{*}{ Lutjanidae } & Aphareus rutilans & Small-toothed Jobfish & Silapa \\
\hline & & Etelis carbunculus & Ruby Snapper & Silapa \\
\hline & & Lutjanus malabaricus & Saddle-tailed Seaperch & Gaca \\
\hline & & L. monostigma & One-spot Snapper & Gaca \\
\hline & & L. rivulatus & Maori Seaperch & Gaca \\
\hline & & L. bitaeniatus & Indonesian Snapper & Gorara/Kasuari \\
\hline & & Caesio caerulaureus & Blue and gold Fusiler & Lalosi \\
\hline & \multirow[t]{3}{*}{ Carangidae } & Caranx ignobilis & Giant trevally & Bubara \\
\hline & & C. melampygus & Bluefin Trevally & Bubara \\
\hline & & Alectis ciliaris & Pennantfish & Bubara \\
\hline & Mullidae & Parupenus pleurostigma & Sidespot Goatfish & Salmaneti \\
\hline & Acanthuridae & Acanthurus sp & & Kuli pasir \\
\hline & Priacanthidae & $\begin{array}{l}\text { Heteropriacanthus } \\
\text { cruentatus }\end{array}$ & Bulleye & Mata bulan \\
\hline & Sphyraenidae & Sphyraena barracuda & Great Barracuda & Walo-walo \\
\hline & Haemulidae & Plectorhynchus sp & & Raja bau \\
\hline \multirow[t]{2}{*}{ Beryciformes } & \multirow[t]{2}{*}{ Holocentridae } & Myripristis murdjan & Crimson Soldierfish & Skor \\
\hline & & M. vitatta & Soldierfish & Skor \\
\hline
\end{tabular}

dari daerah terumbu karang mencapai sekitar 5 ton $/ \mathrm{km}^{2}$. Studi di Pillipina dilaporkan hasil perikanan yang dikaitkan dengan terumbu karang secara rata-rata mencapai 15,6 ton $/ \mathrm{km}^{2} /$ thn atau bervariasi antara $2,7-36,9$ ton $/ \mathrm{km}^{2} / \mathrm{thn}$ (White dan Cruz-Trinidad, 1998) yang merupakan hasil terumbu karang dengan kondisi baik, dengan potensi produksi tahunan dapat mencapai sekitar 350.000 ton (Alcala dan Russ, 2002). Hasil studi di Karibia dilaporkan mencapai 0,5 - 5,0 ton $/ \mathrm{km}^{2} /$ thn (Burke dan Maidens, 2004). Adapun di Indonesia berdasarkan kondisi perairan karangnya diperkirakan produksinya bisa mencapai sekitar 10 - 30 ton $/ \mathrm{km}^{2} /$ thn (WWF, $1994 \mathrm{diacu}$ di dalam Supriharyono, 2007), sedangkan Cesar (1996) memperkirakan hasil produksi ikan karang Indonesia mencapai $5-\mathbf{1 0} \%$ dari total produksi ikan. 
McAllister (1998) mengklasifikasikan hasil tangkapan yang dihubungkan dengan kondisi terumbu karang dalam tiga taksiran, yaitu: (i) terumbu karang dalam kondisi sangat baik (excellent) 18 ton $/ \mathbf{k m}^{2} / \mathrm{thn}$; (ii) kondisi baik (good) 13 ton $/ \mathrm{km}^{2} / \mathrm{thn}$; dan (iii) kondisi cukup (fair) 8 ton $/ \mathrm{km}^{2} / \mathrm{thn}$. Dengan demikian hasil tangkapan ikan karang di lokasi studi dalam hubungannya dengan status terumbu karang tidak berbeda jauh dengan apa yang menjadi taksiran oleh McAllister (1998) tersebut. Produktifitas terumbu karang hasil studi ini juga mendukung apa yang dikemukakan oleh Russ (1991), yang menaksir hasil tangkapan ikan karang antara $0,42-36,9$ ton $/ \mathrm{km}^{2} / \mathrm{thn}$, yang merupakan hasil dari rangkuman 18 studi untuk terumbu karang kecil di Asia Tenggara dan Pasifik.

Keragaman hasil tangkapan ini dapat disebabkan oleh berbagai faktor (Russ, 1991), yaitu: (i) ukuran yang berbeda dari terumbu karang; (ii) tingkat upaya; (iii) definisi dari total area terumbu; dan (iv) definisi dari ikan terumbu karang. Dalam studi ini, dalam kaitannya dengan volume hasil tangkapan, fakta di lapangan menunjukkan bahwa volume hasil tangkapan nelayan ini ditentukan pula oleh ukuran ikan hasil tangkapan. Seperti untuk untuk jenis ikan karang dari famili Carangidae, Seranidae, dan Lutjanidae yang pada umumnya mempunyai ukuran yang relatif lebih besar dibanding yang lainnya. Disamping itu ditentukan pula oleh alat dan cara penangkapan, seperti pada jenis ikan karang Caesio caerulaureus (lalosi), hasilnya lebih banyak dengan menggunakan alat tangkap jaring.

Nilai Ekonomi Aktual Terumbu Karang TWP Laut Banda

Nilai ekonomi perikanan karang di Kepulauan Banda dari aktivitas perikanan karang adalah sebagai berikut: penerimaan total $\mathrm{Rp}$ 1.013.409.034/perahu/thn (NPV Rp 6.082.886.123), penerimaan bersih $\mathrm{Rp}$ 916.311.423/perahu/thn (NPV Rp 5.500.067.448), nilai tambah (rente ekonomi) Rp 878.712.91/perahu/thn (NPV Rp 5.274.383.028). Dikarenakan ekstraksi ikan karang dilakukan oleh para nelayan itu sendiri, dalam artian tidak menggunakan tenaga kerja, dengan demikian pendapatan perahu (surplus produsen) nilainya sebesar nilai tambah atau rente ekonomi.

Untuk mendapatkan nilai aktual ekonomi terumbu karang Kepulauan Banda, nilai ekonomi perikanan karang ini diagregasikan dengan jumlah perahu penangkapan per tahun (Tabel 2) (Gustavson, 1998; Cesar et al., 2002; Fauzi dan Anna, 2005; Lestaluhu, 2008). Dalam studi ini tercatat sebanyak 31 perahu penangkapan (nelayan perikanan karang). Nilai aktual ekonomi terumbu karang Kepulauan Banda seluas 15 ha adalah sebesar Rp 878.712.391 (NPV Rp 5.274.383.028), dimana untuk jasa tempat pengasuhan sebesar Rp 439.356.196 (NPV Rp 2.637.191.514), demikian pula untuk jasa tempat dan mencari makan $\begin{array}{lllll}\text { sebesar } & \text { sebesar } & R p & 439.356 .196 & \text { (NPV }\end{array}$ Rp 2.637.191.514).

Tabel 2. Nilai aktual ekonomi terumbu karang di Kepulauan Banda ( $R p)$

\begin{tabular}{lccc}
\hline \multirow{2}{*}{$\begin{array}{c}\text { Indikator } \\
\text { Ekonomi }\end{array}$} & Tempat pengasuhan & $\begin{array}{c}\text { Tempat Mencari } \\
\text { Makan }\end{array}$ & Total Fungsi \\
\cline { 2 - 4 } & & Nilai Aktual Ekonomi & \\
\hline Surplus produsen & 439.356 .196 & 439.356 .196 & 878.712 .391 \\
\hline & & Net Present Value (13,66 \%) & \\
\hline Surplus produsen & 2.637 .191 .514 & 2.637 .191 .514 & 5.274 .383 .028 \\
\hline Sumber: Data Primer, 2011 & & &
\end{tabular}

3.2. Nilai Ekonomi Terumbu Karang Rp 175.812.768 (Tabel 3). Nilai kapitalisasi PV Kepulauan Banda per Hektar

Nilai kapitalisasi (NPV) asset sumber daya terumbu karang Kepulauan Banda bila di bagi per luasan (ha), diperoleh $P V$ Benefit sebagai berikut: untuk jasa tempat pengasuhan Rp 202.762.871/ha dan mencari makan Rp 202.762.871/ha. PV Residual Rent sebagai berikut: untuk jasa tempat pengasuhan Rp 175.812.768/ha dan mencari makan benefit merupakan nilai sekarang per hektar dari asset sumber daya terumbu karang, dan $P V$ residual rent merupakan nilai sekarang sebagai perubahan antara biaya faktor produksi dari nilai panen dari sumber daya terumbu karang per hektar, yang merupakan kontribusi sistem alam atau faktor pendapatan terhadap nilai ekonomi total (Barton, 1994). 
Tabel 3. Nilai ekonomi terumbu karang Kepulauan Banda per hektar

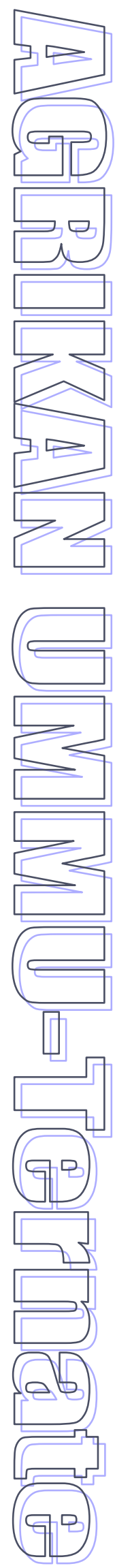

\begin{tabular}{lccc}
\hline \multirow{2}{*}{ Indikator Ekonomi } & \multicolumn{3}{c}{ Net Present Value per Hektar (Rp/ha) } \\
\cline { 2 - 4 } & Tempat pengasuhan & Tempat Mencari Makan & Total Fungsi \\
\hline PV Benefit & 202.762 .871 & 202.762 .871 & 405.525 .742 \\
PV Residual Rent & 175.812 .768 & 175.812 .768 & 351.625 .535 \\
\hline
\end{tabular}

Sumber: Data Primer, 2011

\section{PENUTUP}

\subsection{Simpulan}

Berdasakan hasil analisis yang telah diuraikan sebelumnya, dapat ditarik kesimpulan sebagai berikut:

1. Produksi perikanan karang di kawasan perairan terumbu karang Kepulauan Banda yang luasnya 15 hektar $\left(0,15 \mathrm{~km}^{2}\right)$ dalam kondisi baik dengan tutupan 50-75\% menghasilkan ikan karang sebanyak 54.539 $\mathrm{kg} /$ tahun.

2. Terumbu karang Kepulauan Banda yang luasnya 15 ha $\left(0,15 \mathrm{~km}^{2}\right)$ nilai ekonomi aktual NPV sebesar Rp 5.274.383.028, dalam jangka panjang dengan suku bunga sebesar $13,66 \%$ per tahun. Merupakan nilai lestari dari terumbu karang yang terlindungi dari ancaman manusia. Nilai ini menunjukkan nilai ekonomi untuk jasa tempat pengasuhan dan mencari makan, masingmasing NPV sebesar Rp 2.637.191.514.

\subsection{Saran}

Nilai ekonomi aktual hasil studi ini mencerminkan nilai asset sumberdaya terumbu karang Kepulauan Banda. Nilai ekonomi ini dapat dijadikan sebagai bahan pertimbangan dalam pengelolaan kawasan perairan Kepulauan Banda. Kebijakan pemanfaatan atau pembangunan di kawasan perairan Kepulauan Banda diharapkan tidak sampai menurunkan manfaat ekonomi yang ada, idealnya manfaat ekonomi dari sebuah kebijakan pembangunan dapat memberikan nilai yang lebih, kalau tidak setara.

\section{DAFTAR PUSTAKA}

Acosta CA. and Robertson DN. 2002. Diversity in coral reef fish communities: the effects of habitat patchiness revisited. Mar. Ecol. Prog. Ser. 227: 87-96.

Adger N., Katrina B., Raffaello C., and Dominic M. 1994. Towards estimating total economic value of forests in Mexico. Centre of Sosial Economic Reaserch of the Global Environment, University of East Anglia and University College London. CSERGE working paper GEC 94-21.

Adrianto L. 2002. Modul Pengenalan Konsep dan Metodologi Valuasi Ekonomi Sumberdaya Pesisir dan Laut. Program Studi Ekonomi Sumberdaya Kelautan Tropika, Sekolah Pascasarjana IPB.

Allen GR. and Robertson DR. 1997. An annotated checklist of the fishes of Clipperton Atoll, tropical eastern Pacific. Rev. Biol. Trop. 45(2): 813-843.

Anderson K. 2002. A Study of Coral Reef Fishes along a Gradient of Disturbance in the Langkawi Archipelago, Malaysia. Undergraduate thesis in biology, Departemen of Animal Ecology, Uppsala University, Sweden. http://www. coralcay.org/science/publications/philippines_m_2001_dunjungan3_fish.pdf. Rabu, 17 Mei 2006.

Barnes RSK. And Hughes RN. 2004. An Introduction to Marine Ecology Third Edition. Blackwell Publishing. Australia.

Barton DN. 1994. Economic Factors and Valuation of Tropical Coastal Rsources. SMR-report 14/94. Universitetet I Bergen Senter for Miljø-OG Ressursstudier.

Bell JD. and Galzin R. 1984. Influence of live coral cover on coral reef-fish communities. Mar. Ecol. Prog. Ser 15: 265-274. 
Burk L., Selig E., and Spalding M. 2002. Reefs at Risk in Southeast Asia. Worls Resources Institute.

Chabanet P., Ralambondrainy H., Amanieu M., Faure G. and Galzin R. 1997. Relationships between coral reef substrata and fish. Coral Reefs 16: 93-102.

Choat JH. and Bellwood DR. 1991. Reef fishes: their history and evolution. In: Sale PF. (ed.). 1991. The Ecology of Fishes on Coral Reefs. Academic Press, San Diego.

Dinas Kelautan dan Perikanan Provinsi Maluku. 2005. Penyusunan Data Spasial Sumberdaya Perikanan dan Kelautan Provinsi Maluku.

Djuharsa E. and Suhendi L. 2002. Facts on Banda Islands: Topography, climate, socio-economics and the fishing industry. In: Mous PJ. (ed.). 2002. Report on a rapid ecological assessment of the Banda Islands, Maluku, Eastern Indonesia, held April 28 - May 2 2002. The Nature Concervacy - Southeast Asia Center for Marine Protected Areas.

Eckert GJ. 1987. Estimates of adult and juvenile mortality for labrid fishes at One Tree Reef, Great Barrier Reef. Marine Biology 95(2): 167-171.

Eggleston DB. 1995. Recruitment in Nassau grouper Epinephelus striatus: post-settlement abundance, microhabitat features, and ontogenetic habitat shifts. Mar. Ecol. Prog. Ser 124(1-3): 9-22.

Fauzi A. 2004. Ekonomi Sumber Daya Alam dan Lingkungan. Teori dan Aplikasi. PT Gramedia Pustaka Utama. Jakarta.

Fauzi A. dan Anna S. 2005. Studi Valuasi Ekonomi. Perencanaan Kawasan Konservasi Selat Lembeh, Sulawesi Utara. Naskah akademik pengelolaan kawasan konservasi laut selat Lembeh.

Halford A. 2002. Reef fish biodiversity of the Banda Islands, Eastern Indonesia. In: Mous PJ. (ed.). 2002. Report on a rapid ecological assessment of the Banda Islands, Maluku, Eastern Indonesia, held April 28 - May 2 2002. The Nature Concervacy - Southeast Asia Center for Marine Protected Areas.

Hallacher LE. 2003. The ecology of coral reef fishes. University of Hawaii, Hilo. http://kmec.uhh.hawaii.edu/QUESTInfo/Coral $\% 20$ Reef $\% 20$ Fishes $\% 20-\% 20$ May\%202003.pdf Senin, 25 Februari 2008.

Juanda B. 2007. Metodologi Penelitian Ekonomi dan Bisnis. IPB Press. Bogor.

Jones GP., Mark IM., Maya S., and Janelle VE. 2004. Coral decline threatens fish biodiversity in marine cadangans. Proceedings of the National Academy of Sciences of the United States of America 101(21): 8251-8253.

Leis JM. 1991. The pelagic stage of reef fishes: the larval biology of coral reef fishes. In: Sale PF. (ed.). 1991. The Ecology of Fishes on Coral Reefs. Academic Press, San Diego.

Luckhurst BE. and Luckhurst K. 1978. Analysis of the influence of substrate variables on coral reef fish communities. Marine Biology 49:317-323.

McClanahan TR. 1994. Kenyan coral reef lagoon fish: effects of fishing, substrate complexity and sea urchins. Coral Reefs 13:231-241.

Medrizam, Pratiwi S., dan Wardiyono. 2004. WILAYAH KRITIS KEANEKARAGAMAN HAYATI DI INDONESIA: instrument penilaian dan pemindaian indikatif/cepat bagi pengambil kebijakan. sebuah studi kasus ekosistem pesisir laut. BAPPENAS.

Mayer CG., Holland KN., Wetherbee BM., and Lowe CG. 2001. Diet, resource partitioning and gear vulnerability of Hawaiian jacks captured in fishing tournaments. Fish. Res. 53. 105-113.

Nybakken JW. 1992. Biologi Laut. Suatu Pendekatan Ekologis (alih bahasa dari Marine Biology : An Ecologycal Approach, Oleh : M. Eidman, Koesoebiono, DG. Bengen, M. Hutomo, dan S. Suardjo). PT Gramedia. Jakarta.

Peristiwady T. 2006. Ikan-ikan laut ekonomis penting di Indonesia. Petunjuk Identifikasi. LIPI Press, Jakarta.

Prawiro RH. 1983. Ekonomi Sumber Daya. Alumni. Jakarta.

Roberts CM. and Ormond RFG. 1987. Habitat complexity and coral reef fish diversity and abundance on Red Sea fringing reefs. Mar. Eco. Prog. Ser. 41:18. 


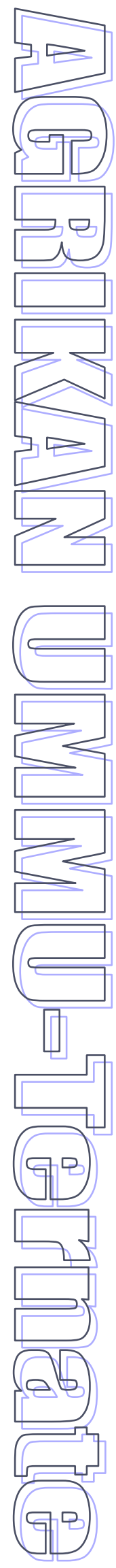

Robertson DR. and Gaines SD. 1986. Interference competition structures habitat use in a local assemblage of coral reef surgeonfishes. Ecology 67(5): 1372-1383.

Terumbu Karang Indonesia (Terangi). 2000. Banda Islands Coastal Ecosystems. Collection and Analysis of Secondary Data. Jakarta.

Thresher RE. 1991. Geographic variability in the ecology of coral reef fishes: evidence, evolution, and possible implications. In: Sale PF. (ed.). 1991. The Ecology of Fishes on Coral Reefs. Academic Press, San Diego.

Turak E., Wakeford M. and Done T. 2002. Assessment of Coral Biodiversity and Coral Reef Healt. In: Mous PJ. (ed.). 2002. Report on a rapid ecological assessment of the Banda Islands, Maluku, Eastern Indonesia, held April 28 - May 2 2002. The Nature Concervacy Southeast Asia Center for Marine Protected Areas.

Yakin A. 2004. Ekonomi Sumberdaya Dan Lingkungan. Teori dan Kebijaksanaan Pembangunan Berkelanjutan. Akademi Presindo. Jakarta.

Westmacott S., Teleki K., Wells S., and West J. 2000. Management of Bleached and Severely Damaged Coral Reefs. IUCN, Gland, Switzerland and Cambridge, UK. 